\title{
Immune checkpoint inhibitors and type 1 diabetes mellitus: a case report and systematic review
}

\author{
Jeroen M K de Filette', Joeri J Pen², Lore Decoster ${ }^{3}$, Thomas Vissers ${ }^{4}$, Bert Bravenboer ${ }^{1}$, Bart J Van der Auwera ${ }^{5}$, \\ Frans K Gorus ${ }^{5}$, Bart O Roep ${ }^{6,7}$, Sandrine Aspeslagh ${ }^{3}$, Bart Neyns ${ }^{3}$, Brigitte Velkeniers ${ }^{1}$ and \\ Aan V Kharagjitsingh ${ }^{1,2,5,8}$
}

${ }^{1}$ Department of Endocrinology, ${ }^{2}$ Diabetes Clinic, ${ }^{3}$ Department of Medical Oncology, Universitair Ziekenhuis Brussel, Brussels, Belgium, ${ }^{4}$ Medical Library, Haaglanden Medical Center, Hague, The Netherlands, ${ }^{5}$ Diabetes Research Center, Vrije Universiteit Brussel, Brussels, Belgium, ${ }^{6}$ Department of Immunohematology \& Blood Transfusion, Leiden University Medical Center, Leiden, The Netherlands, ${ }^{7}$ Department of Diabetes Immunology, Diabetes \& Metabolism Research Institute, City of Hope, Duarte, California, USA, and ${ }^{8}$ Section Endocrinology, Department of Internal Medicine, Leiden University Medical Center, Leiden, The Netherlands

Correspondence should be addressed to J M K de Filette Email

jdefilet@vub.ac.be

\begin{abstract}
Objective: To better define the rare adverse event (AE) of diabetes mellitus associated with immune checkpoint inhibitors (ICls).

Design and methods: We report the case of a lung cancer patient with diabetic ketoacidosis (DKA) and autoimmune thyroiditis during pembrolizumab treatment. We provide a systematic review of all published cases (PubMed/Web of Science/Cochrane, through November 2018) of autoimmune diabetes mellitus related to blockade of the cytotoxic T-lymphocyte antigen 4 (CTLA-4)-, programmed cell death 1 (PD-1) receptor or its ligand (PD-L1) or combination (ICI) therapy.

Results: Our literature search identified 90 patient cases (our case excluded). Most patients were treated with anti-PD-1 or anti-PD-L1 as monotherapy (79\%) or in combination with CTLA-4 blockade (15\%). On average, diabetes mellitus was diagnosed after 4.5 cycles; earlier for combination ICl at 2.7 cycles. Early-onset diabetes mellitus (after one or two cycles) was observed during all treatment regimens. Diabetic ketoacidosis was present in $71 \%$, while elevated lipase levels were detected in 52\% (13/25). Islet autoantibodies were positive in 53\% of patients with a predominance of glutamic acid decarboxylase antibodies. Susceptible HLA genotypes were present in 65\% (mostly DR4). Thyroid dysfunction was the most frequent other endocrine AE at $24 \%$ incidence in this patient population.

Conclusion: ICI-related diabetes mellitus is a rare but often life-threatening metabolic urgency of which health-care professionals and patients should be aware. Close monitoring of blood glucose and prompt endocrine investigation in case of hyperglycemia is advisable. Predisposing factors such as HLA genotype might explain why some individuals are at risk.
\end{abstract}

\section{Introduction}

Unleashing the power of the immune system with monoclonal antibodies targeting immune checkpoint receptors has been a major breakthrough causing a paradigm shift in the treatment of many types of cancer. The deficient anti-tumor immune response can be restored by blocking inhibitory immune receptors of which cytotoxic T-lymphocyte antigen 4 (CTLA-4), programmed cell death 1 receptor (PD-1) and its ligand https://eje.bioscientifica.com https://doi.org/10.1530/EJE-19-0291 Printed in Great Britain 
(PD-L1) have become part of our standard of care options in many indications (1). Immune checkpoint blockade is associated with a unique risk for immune-related AEs (irAE), affecting the endocrine organs in $4-30 \%$ of patients $(2,3)$. While hypophysitis and thyroid disorders are the most frequent endocrine irAE, autoimmune diabetes mellitus is a rare (1\%) but potentially life-threatening irAE deserving further notice (4). It appears more frequently with PD-1 or PD-L1 blockade (or combination therapy) than with anti-CTLA-4 (ipilimumab) therapy $(5,6)$, highlighting the importance of the PD-1/PD-L pathway in maintaining self-tolerance against pancreatic islets. Similarities with 'classic' type 1 diabetes mellitus (T1D) include the presence of islet antibodies and susceptible HLA genotypes $(4,6)$. The clinical significance of diabetes mellitus associated with checkpoint blockade is estimated to increase as these novel anticancer agents are both initiated to a greater extent and at an earlier disease stage (7). We describe a patient with rapid-onset diabetes mellitus and ketoacidosis associated with the ICI pembrolizumab (anti-PD-1). We subsequently performed a systematic review and present an overview of similar cases of diabetes mellitus related to CTLA-4, PD-1, PD-L1 or a combination of CTLA-4 and PD-1 checkpoint inhibitors. We discuss the clinical presentation, potential mechanisms and suggestions for optimal management.

\section{Case report}

Our patient is a 61-year-old male with a recent diagnosis of metastatic non-small-cell lung carcinoma (NSCLC). Eight weeks after initiating treatment with pembrolizumab, he presented at the emergency department with a 5-day history of nausea, vomiting, diarrhea and generalized weakness. He had no personal or family history of endocrine or autoimmune disease. Physical examination revealed impaired consciousness, dry mouth, marbled skin and cold extremities. He was hypotensive $(105 / 45 \mathrm{mmHg})$ and tachycardic (108/min). Blood analysis showed a marked hyperglycemia $(1194 \mathrm{mg} /$ $\mathrm{dL}=66.3 \mathrm{mmol} / \mathrm{L})$, pseudohyponatremia $(117 \mathrm{mmol} / \mathrm{L}$ corrected $143 \mathrm{mmol} / \mathrm{L}$ ) (8) and acute renal insufficiency $\left(\mathrm{CrCl} 28 \mathrm{~mL} / \mathrm{min} / 1.73 \mathrm{~m}^{2}\right)$. The positive reaction for urinary ketones and a blood gas analysis showing severe metabolic acidosis with respiratory compensation, established the diagnosis of diabetic ketoacidosis. The patient was hospitalized at our intensive care unit for monitoring, rehydration and intravenous insulin therapy. He recovered and was switched to a subcutaneous basal-prandial insulin regimen. An autoimmune etiology was probable, given the context and the presence of positive glutamic acid decarboxylase autoantibodies (GADAs) with low C-peptide levels (Table 1). The serum lipase level was also elevated at diagnosis ( $>3$ times the upper reference limit). Abdominal computed tomography did not show signs of pancreatitis. The HLA class II genotype of our case was assessed by allele-specific oligonucleotide hybridization, as previously described (9). HLA genotype analysis identified homozygosity for the haplotype DRB1*04-DQA1*03:01-DQB1*03:02 (DR4-DQ8). Subclinical hyperthyroidism was simultaneously detected (TSH $0.058 \mathrm{mIU} / \mathrm{L}, \quad$ fT $4 \quad 18.7 \mathrm{pmol} / \mathrm{L}$ ) which evolved into manifest hypothyroidism (TSH $18.92 \mathrm{mIU} / \mathrm{L}$, fT4 $5.7 \mathrm{pmol} / \mathrm{L}$ ) over the next weeks requiring levothyroxine substitution therapy. Ultrasonography of the thyroid did not demonstrate hypervascularity, and thyroid autoantibodies (TPOAb, TSI) were negative. This clinical pattern was suggestive of checkpoint blockade-induced thyroiditis $(10,11,12,13)$. We subsequently performed a systematic review to identify similar cases of diabetes mellitus associated with ICI.

\section{Methods}

Several databases (PubMed/Web of Science/Cochrane) were searched through November 2018, for case reports on the subject of diabetes mellitus and checkpoint inhibitors, by two reviewers independently (J M K d F and A V K). The investigators screened the title and abstract for manuscript selection. Language was restricted to English. Congress reports were excluded. Supplementary Table 1 (see section on supplementary data given at the end of this article) provides an overview of our search terms. Additionally, the authors reviewed the reference lists of the included articles $(4,13,14,15,16,17,18,19$, $20,21,22,23,24,25,26,27,28,29,30,31,32,33,34$, $35,36,37,38,39,40,41,42,43,44,45,46,47,48,49$, $50,51,52,53,54,55,56,57,58,59,60,61,62,63,64$, $65,66,67,68)$ and identified five additional cases $(69$, $70,71,72)$. The following data were extracted from each manuscript: author, year of publication, age, gender and ethnicity of the patient, cancer type, checkpoint inhibitor therapy, number of cycles of therapy, prior immunotherapy, relevant past medical history (PMH), presence of diabetic ketoacidosis, glycemia, glycated hemoglobin, C-peptide, islet autoantibodies, lipase, other irAE and HLA genotype. The number of treatment cycles was preferred rather than the time to onset 
Table 1 Laboratory data on admission.

\begin{tabular}{|c|c|c|}
\hline & Value & Ref. \\
\hline \multicolumn{3}{|l|}{ Blood } \\
\hline Glucose, mg/dL & 1194 & $70-100$ \\
\hline Urea, mg/dL & 96 & $19-43$ \\
\hline Creatinine, $\mathrm{mg} / \mathrm{dL}$ & 2.4 & $0.66-1.25$ \\
\hline eGFR (MDRD; mL/min/1.73 $\mathrm{m}^{2}$ ) & 28 & $>60$ \\
\hline $\mathrm{Na}, \mathrm{mmol} / \mathrm{L}$ & 117 & $137-145$ \\
\hline $\mathrm{K}, \mathrm{mmol} / \mathrm{L}$ & 5.6 & $3.4-5.0$ \\
\hline $\mathrm{Cl}, \mathrm{mmol} / \mathrm{L}$ & 86 & $98-107$ \\
\hline $\mathrm{HCO}_{3}, \mathrm{mmol} / \mathrm{L}$ & 6 & $22-30$ \\
\hline Anion Gap, mmol/L & 31 & $10-18$ \\
\hline $\mathrm{Ca}, \mathrm{mmol} / \mathrm{L}$ & 1.86 & $2.10-2.50$ \\
\hline $\mathrm{P}, \mathrm{mmol} / \mathrm{L}$ & 0.77 & $0.81-1.45$ \\
\hline $\mathrm{Mg}, \mathrm{mmol} / \mathrm{L}$ & 0.95 & $0.66-0.95$ \\
\hline Alb, g/L & 31 & $35-50$ \\
\hline $\mathrm{CRP}, \mathrm{mg} / \mathrm{L}$ & 100.3 & $<5$ \\
\hline $\mathrm{LDH}, \mathrm{U} / \mathrm{L}$ & 408 & $313-618$ \\
\hline AST, U/L & 16 & $17-59$ \\
\hline $\mathrm{ALT}, \mathrm{U} / \mathrm{L}$ & 29 & $21-72$ \\
\hline$A L P, U / L$ & 113 & $38-126$ \\
\hline GGT, U/L & 36 & $<73$ \\
\hline Bili, mg/dL & 0.43 & $0.2-1.3$ \\
\hline Lipase, U/L & 970 & $23-300$ \\
\hline Platelet, $\times 10^{3} / \mathrm{mm}^{3}$ & 305 & $158-450$ \\
\hline $\mathrm{Hb}, \mathrm{g} / \mathrm{dL}$ & 14.3 & $13.0-16.5$ \\
\hline WBC, $\times 10^{3} / \mathrm{mm}^{3}$ & 21.9 & $3.6-9.6$ \\
\hline Neutrophils, $\%$ & 86.0 & $41.0-74.0$ \\
\hline (Absolute), $\times 10^{3} / \mathrm{mm}^{3}$ & 18.834 & $1.4-6.7$ \\
\hline \multicolumn{3}{|l|}{ Urine } \\
\hline Protein & Negative & \\
\hline \multirow[t]{2}{*}{ Glucose, g/L } & ++++ & \\
\hline & 44.3 & \\
\hline Creatinine, mg/dL & 25 & \\
\hline $\mathrm{Na}, \mathrm{mmol} / \mathrm{L}$ & 10 & \\
\hline Osm, mosmol/kg $\mathrm{H}_{2} \mathrm{O}$ & 418 & \\
\hline \multicolumn{3}{|l|}{ Arterial blood gas } \\
\hline $\mathrm{pH}$ & 6.944 & $7.35-7.45$ \\
\hline $\mathrm{PaCO}_{2}, \mathrm{mmHg}$ & 18.5 & $36-44$ \\
\hline $\mathrm{PaO}_{2}, \mathrm{mmHg}$ & 86.5 & $65-80$ \\
\hline $\mathrm{HCO}_{3}, \mathrm{mmol} / \mathrm{L}$ & 4.0 & $22-26$ \\
\hline Base excess, mmol/L & -26.2 & $-2,+2$ \\
\hline Lactate, $\mathrm{mmol} / \mathrm{L}$ & 1.6 & $0.7-2.1$ \\
\hline \multicolumn{3}{|c|}{ Thyroid (before the start of immunotherapy) } \\
\hline $\mathrm{TSH}, \mathrm{mIU} / \mathrm{L}$ & 1.11 & $0.27-4.2$ \\
\hline fT4, pmol/L & 12.4 & $11.0-24.0$ \\
\hline \multicolumn{3}{|l|}{ Diabetes } \\
\hline ICA & Negative & \\
\hline Insulin Ab, \% binding & 0.5 & $<0.6$ \\
\hline GADA, WHO U/mL & $>171$ & $<23$ \\
\hline $\mathrm{IA} 2 \mathrm{~A}, \mathrm{WHO} \mathrm{U} / \mathrm{mL}$ & $<0.1$ & $<1.4$ \\
\hline C-peptide, $\mathrm{nmol} / \mathrm{L}$ & 0.02 & $0.29-0.99$ \\
\hline
\end{tabular}

in weeks, as this information was not consistently available (immune checkpoint therapy is usually given every 3 weeks). We categorized the HLA haplotype into three classes: 'susceptible', 'neutral' or 'protective' for autoimmune diabetes. Specifically, haplotypes were categorized as susceptible in the presence of (1) HLA
A2, DR3, DR4 or (2) the presence of DR9 in a Japanese population or (3) when the authors of the original paper had categorized it susceptible. They were protective in case of DQ6, DR11 or DR16-DQ5. Written informed consent for genetic analysis and publication was obtained from our patient.

\section{Results}

Our search identified a total of 145 articles of which 62 were eligible. Figure 1 shows a flow chart of the study selection. We identified a total of 90 cases, aside from our patient, with a male predominance $(55 / 91,60 \%)$ and a mean age of 61 years (range 22-84). The ethnicity was Asian in 15\%. The main tumor types were melanoma (48/91, 53\%) and NSCLC (14/91, 15\%). Relevant PMH, namely diabetes mellitus, thyroid disease or risk thereof, was noted in $22 \%(20 / 91)$. One in four cases $(22 / 91,24 \%)$ had received prior immunotherapy, with IL-2 (2/91), interferon (7/91), ipilimumab (16/91) and/or nivolumab (3/91). The different treatment regimens included monotherapy with anti-CTLA-4 (3/91, 3\%), anti-PD-1 (65/91, 71\%), anti-PD-L1 $(7 / 91,8 \%)$ or a combination of anti-CTLA-4 with anti-PD-1 (14/91, 15\%). One patient received PD-L1 with 4-1BB (CD137) blockade and one other patient received either CTLA-4 or PD-1 blockade therapy. Thus, the treatment regimen mostly observed in this cohort was anti-PD-1 monotherapy; blockade of the PD-1/PD-L pathway was involved in 96\% (87/91). Only three cases of diabetes development were observed during anti-CTLA-4 monotherapy. Importantly, all of these were pre-treated with nivolumab (2/3) and/or interferon (2/3). On average, patients were diagnosed with diabetes after 4.5 treatment cycles (range: 1-17), while this appeared to be earlier for the combination of anti-CTLA-4 and PD-1 therapy (2.7 cycles, range: 1-5). Cases of early-onset diabetes (after only one or two cycles) were observed in all treatment regimens. The presentation of diabetes mellitus related to checkpoint blockers often follows a severe course. Seventy-one percent of patients (64/91) presented with diabetic ketoacidosis (DKA), with a median presenting glycemia of $565 \mathrm{mg} / \mathrm{dL}$ (range: 209-1211) and glycated hemoglobin of 7.6\% (average: 7.7\%; range: $5.4-11.4$ ). Low C-peptide levels were present at diagnosis in 84\% (58/69) of cases. The onset appeared earlier for patients presenting with DKA, with 4 versus 5.9 cycles. Elevated lipase levels were detected in 52\% (13/25) of analyzed patients. At least one of the islet autoantibodies was positive in $53 \%$ (47/88), while two or more autoantibodies were detected 


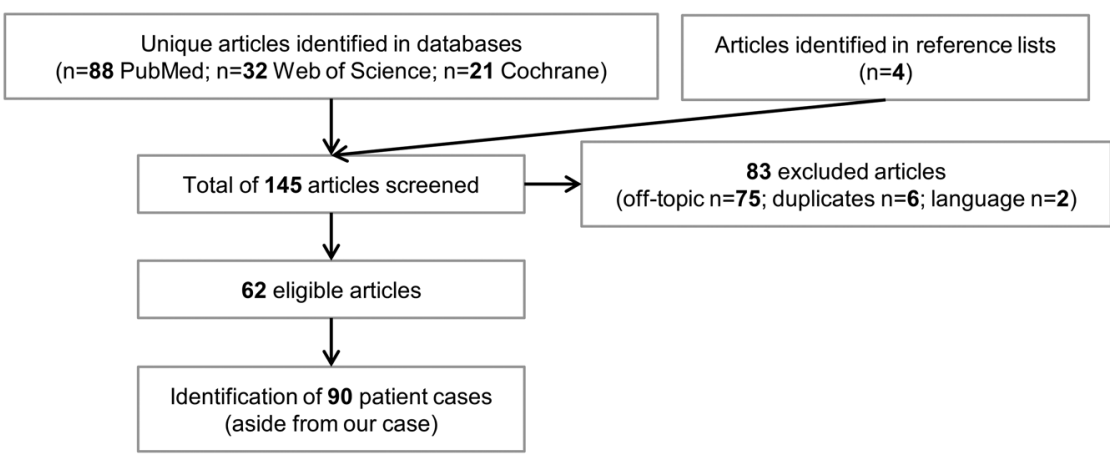

\section{Figure 1}

Flow chart of study selection. in $15 \%(13 / 88)$. The autoantibody analysis was positive in $51 \%$ of patients for GADA, $18 \%$ for insulinoma-associated antigen-2 (IA-2), 13\% for islet-cell antibodies (ICA), 26\% for anti-insulin and 4\% for zinc transporter 8 (ZnT8). Table 2 shows an overview of pancreatic autoantibodies. The mean time of onset was 3.1 cycles (range: $1-17$ ) for GADA-positive and 5.9 cycles (range: 1-16) for GADAnegative patients. The genetic HLA region was analyzed in $56 \%(51 / 91)$ of patients. Genotypes susceptible for T1D or fulminant diabetes were present in 61\% (31/51), while a protective genotype was simultaneously present in an additional 4\% (2/51). The DR4, DR3, DR9 and A2 were the dominant HLA serotypes. Table 3 shows an overview of the HLA genotypes. Thyroid dysfunction related to checkpoint inhibition (thyroiditis, primary hypo- or hyper-thyroidism) developed in 24\% (21/91) of patients. Of these 21 patients, two had a known history of hypothyroidism. A summary of the results can be found in Table 4.

\section{Discussion}

We present a comprehensive overview of diabetes mellitus development in patients treated with ICIs and describe a patient with simultaneous rapid onset of diabetes mellitus with ketoacidosis and thyroiditis associated with the checkpoint inhibitor pembrolizumab. We confirm that diabetes mellitus is an important, yet rare, side effect. Similar to our case, these patients often present with a

Table 2 Pancreatic autoantibodies and ICl-induced diabetes.

\begin{tabular}{|c|c|c|c|c|c|c|}
\hline & All & GAD & ICA & IA-2 & Insulin & ZnT8 \\
\hline Present & 47 & 43 & 3 & 10 & 9 & 1 \\
\hline Absent & 41 & 42 & 20 & 45 & 26 & 23 \\
\hline N/A & 3 & 6 & 68 & 36 & 56 & 67 \\
\hline Frequency (\%) & 53 & 51 & 13 & 18 & 26 & 4 \\
\hline
\end{tabular}

GAD, glutamic acid decarboxylase; IA-2, insulinoma-associated antigen-2; ICA, islet-cell antibodies; N/A, not available; ZnT8, zinc transporter 8. fulminant onset of diabetes mellitus and the presence of ketoacidosis at the time of diagnosis $(4,6,15)$. Its onset ranges from a few weeks, sometimes even after the first or second cycle of immunotherapy $(4,6)$, up to more than a year after the initiation of immunotherapy $(6,17)$. We observed the early pattern of diabetes onset with all classes of checkpoint inhibitors. The onset of $\beta$ cell inflammation is often fulminant, suggested by the relatively low glycated hemoglobin levels, while C-peptide levels are usually low or undetectable at diagnosis. This irAE is predominantly found in patients exposed to blockade of the PD-1/PD-L pathway. We further observed that a quarter of all patients has received prior immunotherapy, and it is possible that this influenced the results, as it was previously observed that the combination of rapamycin and IL-2 transiently decreased C-peptide levels in T1D patients (73), and additionally T1D was also a reported side effect of interferon therapy (74). Islet autoantibodies were detected in half of patients, with GADA being the predominant antibody, although it should be noted that the other autoantibodies were not as systematically analyzed. This differs from 'classic' T1D where autoantibodies are present in $80-95 \%$ of patients $(75,76)$. It has previously been suggested that the presence of autoantibodies at the time of diagnosis is related to an earlier onset of ICI-induced diabetes $(4,6,43,58)$. Our review supports this hypothesis. It would be of academic value to prospectively investigate this phenomenon as well as the serologic status of non-diabetes patients in future studies. Additionally, there

Table 3 HLA genotype in patients with ICl-induced diabetes.

\begin{tabular}{|c|c|c|c|}
\hline HLA genotype & & Serotype & $\#$ \\
\hline Susceptible & $31 / 51(61 \%)$ & A2.1 & 5 \\
\hline Susceptible and protective & $2 / 51(4 \%)$ & DR3 & 8 \\
\hline Neutral & $10 / 51(20 \%)$ & DR4 & 23 \\
\hline Protective & $8 / 51(16 \%)$ & DR9 & 5 \\
\hline \multirow[t]{2}{*}{ N/A } & $40 / 91$ & DR4-DQ4 & 2 \\
\hline & & Other & 15 \\
\hline
\end{tabular}

ICl, immune checkpoint inhibitor; N/A, not available. 
Table 4 Summary of results.

\begin{tabular}{|c|c|}
\hline Characteristic & All cases $(n=91)$ \\
\hline \multicolumn{2}{|l|}{ Age, years } \\
\hline Median (range) & $61(22-84)$ \\
\hline \multicolumn{2}{|l|}{ Gender } \\
\hline Female/male & 36 vs 55 \\
\hline \multicolumn{2}{|l|}{ Ethnicity } \\
\hline Asian & $14 / 91(15 \%)$ \\
\hline \multicolumn{2}{|l|}{ Tumor types } \\
\hline Melanoma & $48 / 91(53 \%)$ \\
\hline NSCLC & $14 / 91(15 \%)$ \\
\hline Past medical history* & 20/91 (22\%) \\
\hline Prior immunotherapy & $22 / 91(24 \%)$ \\
\hline IL-2 & $2 / 91$ \\
\hline Interferon & $7 / 91$ \\
\hline Ipilimumab & $16 / 91$ \\
\hline Nivolumab & $3 / 91$ \\
\hline \multicolumn{2}{|l|}{ Immune checkpoint inhibitor } \\
\hline Anti-CTLA-4 & $3 / 91(3 \%)$ \\
\hline Anti-PD-1 & $65 / 91(71 \%)$ \\
\hline Anti-PD-L1 & $7 / 91(8 \%)$ \\
\hline Anti-CTLA-4 + anti-PD-1 & $14 / 91(15 \%)$ \\
\hline Anti-PD-L1 + 4-1BB blockade & $1 / 91$ \\
\hline CTLA-4 or PD-1 blockade & $1 / 91$ \\
\hline Time-to-diagnosis in cycles (range) & $4.5(1-17)$ \\
\hline Combination therapy & $2.7(1-5)$ \\
\hline With/without DKA & 4 vs 5.9 \\
\hline GADA pos./GADA neg. & 3.1 vs 5.9 \\
\hline Diabetic ketoacidosis & $64 / 91(71 \%)$ \\
\hline Glycemia, median (range) & $565 \mathrm{mg} / \mathrm{dL}(209-1211)$ \\
\hline Glycated hemoglobin, median (range) & $7.6 \%(5.4-11.4)$ \\
\hline Low-C-peptide at diagnosis & $58 / 69(84 \%)$ \\
\hline Elevated lipase & $13 / 25(52 \%)$ \\
\hline \multicolumn{2}{|l|}{ Positive pancreas autoantibodies } \\
\hline At least one & $47 / 88(53 \%)$ \\
\hline Two or more & $13 / 88(15 \%)$ \\
\hline \multicolumn{2}{|l|}{ Type of pancreas autoantibodies } \\
\hline GADA & $51 \%$ \\
\hline IA-2 & $18 \%$ \\
\hline ICA & $13 \%$ \\
\hline Anti-insulin & $26 \%$ \\
\hline ZnT8 & $4 \%$ \\
\hline HLA analysis & $51 / 91(56 \%)$ \\
\hline Susceptible & $31 / 51(61 \%)$ \\
\hline Susceptible and protective & $2 / 51(4 \%)$ \\
\hline Neutral & $10 / 51(20 \%)$ \\
\hline Protective & $8 / 51(16 \%)$ \\
\hline Thyroid dysfunction with ICI & $21 / 91(24 \%)$ \\
\hline Prior history of thyroid dysfunction & $2 / 21$ \\
\hline
\end{tabular}

*Diabetes mellitus, thyroid disease or risk thereof.

4-1BB, CD137; CTLA-4, cytotoxic T lymphocyte antigen 4; DKA, diabetes ketoacidosis; GADA, glutamic acid decarboxylase; HLA, human leukocyte antigen; IA-2, insulinoma-associated antigen-2; ICA, islet-cell antibodies; ICl, immune checkpoint inhibitor; IL-2, Interleukin-2; NSCLC, non-small cell lung cancer; PD-1, programmed cell death protein 1; PD-L1, programmed death-ligand 1; ZnT8, zinc transporter 8.

was biochemical evidence of pancreatic inflammation with elevated lipase levels reported in about $50 \%$ of all cases. Several authors also described radiographic changes in the pancreatic volume during immunotherapy, notably pancreatic enlargement before diabetes onset, followed by a volume decrease $(14,46)$. These findings are often asymptomatic $(6,14)$ as was the case in our patient. It remains unclear to which extent the pancreatic exocrine gland is involved. It has been hypothesized that 'classic' T1D is in fact a combined endocrine-exocrine disease in which the loss of functional $\beta$ cell mass is most clinically apparent (77) and non-specific elevations of amylase and lipase occur in $16-25 \%$ of cases with DKA (78). In the context of checkpoint blockade therapy, asymptomatic elevations of lipase and/or amylase have also been reported in the absence of new-onset diabetes $(79,80)$. Whether these patients are prone to develop diabetes in the future is an additional question to address in prospective studies.

The strength of our study is the broad and extensive investigation with the exploration of different search engines. Our study also has its limitations. The analysis included individual patient data, of whom not all parameters of interest were available. The incidence could not be calculated by the lack of the total number of treated patients. We do believe however that this $\mathrm{AE}$ is still underestimated as it is increasingly being reported, as shown by a recent pharmacovigilance study (81). The incidence of DKA was lower (50.2 vs $71 \%$ ) in their analysis. Another research group described a large case series of 27 patients with insulin-dependent diabetes induced by checkpoint inhibitors. Compared to our analysis, they also reported DKA less frequently (59 vs $71 \%$ ) (6). This might be due to a publication bias in our study toward fulminant presentations, due to an underrepresentation of milder diabetes cases in the literature.

The role of immune checkpoints in the pathophysiology of diabetes mellitus has been investigated in mice and in humans. Non-obese diabetic (NOD) mice develop rapid-onset diabetes following the blockade of PD-1 or PD-L1 but not PD-L2 (82). This corresponds with the finding that pancreatic islets express PD-L1 at low levels in mice (dramatically upregulated in inflamed islets), while PD-L2 expression is not detected $(82,83)$. Definite conclusions remain difficult as PD-L1 also binds to B7-1 (CD-80), itself a ligand for CD-28 and CTLA-4 (84). Specific blockade of the PD-L1:B7-1 interaction preferably induced diabetes in older (13 weeks old) as compared to younger (6-7 weeks old) NOD mice, while the blockade of both PD-L1: PD-1 and PD-L1:B7-1 interactions rapidly induced diabetes in mice of both ages (85). This suggests a multi-faceted role for PD-L1 in diabetogenesis. To the best of our knowledge, there is no evidence of CTLA- 4 expression on pancreatic islets, 
although the transgenic overexpression of anti-CTLA-4 Fv on $\beta$ cells could protect NOD mice from autoimmune diabetes (86). In humans, polymorphisms in the CTLA4 and PD-1 gene confer increased susceptibility to a variety of autoimmune disorders, including T1D $(87,88,89,90$, 91, 92). The CTLA-4 and PD-1/PD-L pathways have been studied in T-cell subsets from patients with 'classic' T1D. Both decreased PD-1 gene expression in peripheral CD4 ${ }^{+}$ $\mathrm{T}$ cells (93) as a low frequency of circulating PD- $1^{+} \mathrm{CD} 4^{+}$ $\mathrm{T}$ cells were found in T1D patients (94). More recently, Granados et al. demonstrated further PD-1 dysregulation as activated peripheral $\mathrm{T}$ cells from children with newonset T1D failed to upregulate PD-1 upon T-cell receptor stimulation (95). Regulatory $\mathrm{T}$ cells $\left(\mathrm{T}_{\text {regs }}\right)$ express both CTLA-4 (96) and PD-1 (97), essential in their activation and suppressive role in peripheral immune tolerance $(97,98,99)$ and a deficiency in the ability to upregulate PD-1 and efficiently use the PD-1/PD-L pathway has been observed in $\mathrm{CD}^{+} \mathrm{CD}^{+} 5^{+} \mathrm{T}_{\text {regs }}$ from T1D patients (100). Furthermore, human pancreatic $\beta$ cells express PD-L1, which is induced by IFN- $\gamma$ (and to a lesser extent IFN- $\alpha$ ). This expression is upregulated in inflamed islets and is associated with $\mathrm{CD}^{+}$T-cell infiltration $(101,102)$. One could hypothesize that $\beta$ cells respond in such a way to attempt to suppress autoreactive $\mathrm{CD}^{+} \mathrm{T}$ cells. Figure 2 illustrates the pathophysiology of immune checkpoint inhibitor-associated diabetes mellitus.

Predisposing factors for ICI-induced diabetes should be better defined. 'Classic' T1D has a strong genetic component, with the HLA class II alleles accounting for up to $50 \%$ of the disease risk (103). Differences between populations and diabetic genotypes do exist, as the DR3-DQ2 and DR4-DQ8 haplotypes are a major risk factor for T1D (103), while the DR4-DQ4 and DR9-DQ9 haplotypes are linked with fulminant diabetes in Asians (104). Our patient was homozygous for the DR4-DQ8 haplotype, an HLA pattern associated with a high risk for type 1 diabetes. In this review, the majority of patients had a HLA genotype with increased susceptibility for either T1D or fulminant diabetes (61\%), which is striking when compared to a Caucasian reference population (susceptible genotypes: 9.1\%; rare, neutral or moderately protective/susceptible genotypes: 23.9\%; protective genotypes: 67.1\%) (105). There was also a predominance of HLA-DR4, similar to the cohort described by Stamatouli et al., although they reported a higher frequency $(16 / 21,76 \%)$ (6). We might consider checkpoint blockade-induced diabetes to be a distinct diabetes subtype, showing typical features of 'classic' T1D and fulminant diabetes. The rapid-onset of diabetes with ketoacidosis, relatively low glycated hemoglobin levels and pancreatic inflammation are suggestive of fulminant diabetes, while the seemingly non-Asian ethnical predominance and the presence of autoantibodies (although less frequent) fit to the 'classic' T1D. Alternatively, checkpoint blockade-induced diabetes mellitus may merely be a heterogeneous collection of variants of autoimmune diabetes, exhibiting the increasingly acknowledged heterogeneity of T1D (106). Table 5 compares the characteristics of the different diabetes subtypes (78, 107, 108, 109, 110, 111, 112, 113). Patients who received immune checkpoint therapy after pretreatment with other immunotherapy also appeared to be at increased risk. The combination of checkpoint blockade therapy carries an increased incidence of irAE as compared to monotherapy (114). In a meta-analysis by Barroso-Sousa et al., patients who received combination immunotherapy were more likely to develop thyroid dysfunction and hypophysitis (2). This may hold true as well for ICI-induced diabetes. Prior autoimmune disease, such as autoimmune thyroid disease (spontaneous or associated with immunotherapy)

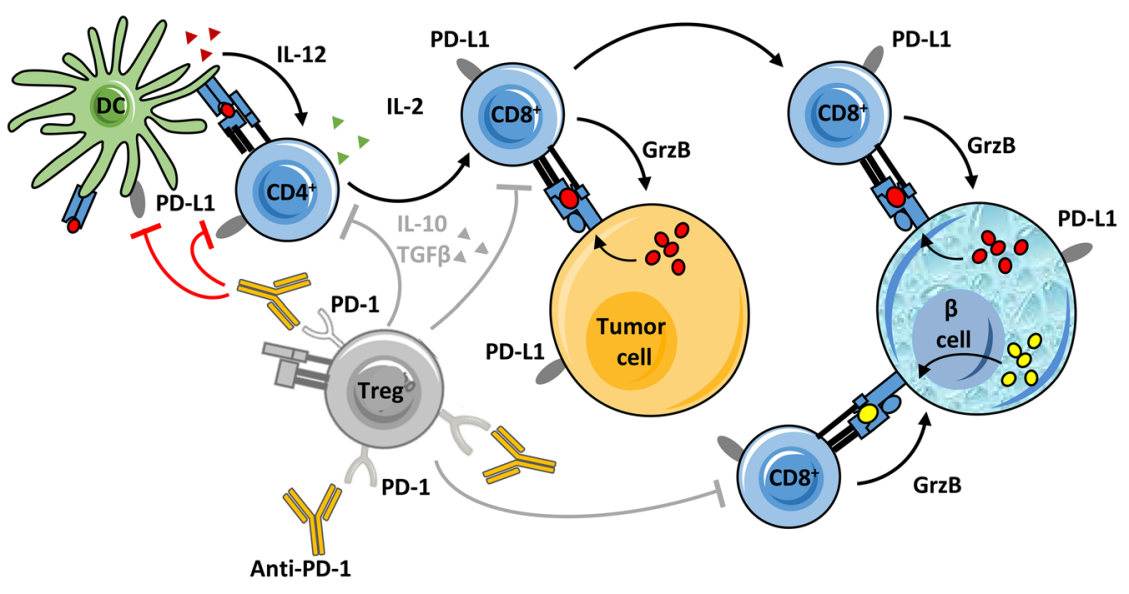

Figure 2

Pathophysiology of immune checkpoint inhibitor-associated diabetes mellitus. 
Table 5 Classification of diabetes mellitus.

\begin{tabular}{|c|c|}
\hline & Checkpoint blockade \\
\hline \multicolumn{2}{|l|}{ Clinical features } \\
\hline Age at onset (range) & 61 years $(22-84)$ \\
\hline Ethnicity & Both \\
\hline Symptoms at diagnosis & Acute (rarely subclinical) \\
\hline Ketoacidosis & Yes (76\%) \\
\hline Insulin required at diagnosis & Yes \\
\hline \multicolumn{2}{|c|}{ Biochemical features (at diagnosis) } \\
\hline C-peptide & Low or undetectable (84\%) \\
\hline HbA1c (range) & $7.5 \%(5.4-11.4)$ \\
\hline Lipase & Elevated (52\%) \\
\hline Autoantibodies & Positive (53\%) \\
\hline \multicolumn{2}{|l|}{ Pathophysiology } \\
\hline HLA association & Suspected \\
\hline
\end{tabular}

\begin{tabular}{l}
\hline 'Classic' type 1 \\
\hline Childhood or adolescence \\
Rarely adult \\
Non-Asian \\
Acute \\
Possible \\
Yes \\
Low or undetectable \\
$>6.35 \%$ \\
Elevated (24\%, DKA) \\
Positive (>80\%) \\
High risk
\end{tabular}

\begin{tabular}{|c|c|}
\hline LADA & Fulminant diabetes \\
\hline$>30$ years & Adult \\
\hline Non-Asian & Asian \\
\hline Subclinical & Acute \\
\hline Rarely & Yes \\
\hline No & Yes \\
\hline Low or normal & Low or undetectable \\
\hline 7.86 & $<8.7 \%$ \\
\hline$?$ & Elevated (98\%) \\
\hline Positive & Negative \\
\hline High/mild risk & High risk \\
\hline
\end{tabular}

References: $(78,107,108,109,110,111,112,113)$.

CRP, C-reactive peptide; HbA1c, glycated hemoglobin; LADA, latent autoimmune diabetes of adults.

could be another potential risk factor for the development of diabetes mellitus related to ICI. The pre-existence of type 2 diabetes did not appear to be a particular risk factor in a French retrospective analysis (25). In this study, one patient with insulin-dependent type 2 diabetes had worsening glycemic control, although it could not be excluded that pancreatic autoimmunity already existed (i.e. LADA) before the start of nivolumab therapy (26).

Health care professionals should be aware of this possible side effect as these novel anticancer agents are increasingly used (7). Clinical signs and symptoms of hyperglycemia should be checked and when present, should prompt blood glucose measurement. Routine monitoring of blood glucose before each administration of ICI therapy is currently advisable $(5,115,116)$. This would theoretically allow for an early diagnosis of glucose abnormalities and of DKA in particular. Some have even suggested to provide a glucometer to patients with a history of autoimmune disease (4). The usefulness of glucose monitoring has been disputed however in a retrospective analysis of fasting glycaemia in anti-PD-1treated patients, suggesting that glucose monitoring does not allow to anticipate T1D in this patient population, perhaps due to its brisk onset (25). Upon the detection of new-onset diabetes or worsening glycaemia in patients with known type 2 diabetes mellitus, the glycated hemoglobin and pancreatic autoantibodies (especially GADA) should be analyzed to support the diagnosis of checkpoint blockade-related diabetes mellitus. Measurement of C-peptide is not strictly necessary for the diagnosis and treatment of this $\mathrm{AE}$, especially given its fluctuation in time, although serially measured (or in the non-DKA phase, glucagon-stimulated) values could be of potential value in future decision-making regarding tapering or omitting insulin therapy in selected cases. The presence of pancreatic autoantibodies, detectable in $~ 50 \%$ of patients, is not an absolute requirement for the diagnosis and treatment of checkpoint inhibitorassociated diabetes. The management is based mainly on clinical expertise with these novel drugs. Insulin is the default therapy for glucose control, together with supportive measures (i.e. hydration, correction of electrolytes) according to standard guidelines (5, 117). There is currently no effective way of preventing or limiting the onset of this side effect. The attempt of immunomodulation with high-dose corticosteroids (i.e. standard treatment of irAE) was unsuccessful in reversing autoimmune diabetes following immunotherapy in a patient described by Aleksova et al. (60). Although omitting checkpoint blockade has been found to prevent further $\beta$ cell loss in a single patient (118), given the compelling indication of immunotherapy in advanced malignancies with few treatment options, this might not be practically possible. This should perhaps be considered in an adjuvant setting where the prognosis is better. Restarting treatment with ICI should be considered once adequate glucose control has been established $(5,117)$. Finally, we acknowledge the need for further prospective studies to reassess/reevaluate current policy and expand our knowledge of the pathophysiology of this unique entity of diabetes mellitus associated with checkpoint inhibitors. Further exploration of risk factors and biomarkers is required to better identify individuals at risk and ideally prevent the onset of this rare but often aggressive form of diabetes. 


\section{Conclusion}

Checkpoint blockade-induced diabetes mellitus is a rare but potentially lethal $\mathrm{AE}$, as diabetic ketoacidosis is often the first presentation. Despite its rarity, healthcare professionals should be aware and patients need to be educated. This is crucial since a growing number of patients are treated with checkpoint blockade. Apart from raising awareness, periodic measurement of blood glucose is a practical screening option, for the time being. Predisposing factors, such as HLA genotype, may explain why some individuals are at greater risk. Our current knowledge of biomarkers, for the stratification of patients that need close follow-up, remains insufficient.

\section{Supplementary data}

This is linked to the online version of the paper at https://doi.org/10.1530/ EJE-19-0291.

\section{Declaration of interest}

Jeroen M K de Filette: lecture honoraria from Bristol-Myers Squibb. Lore Decoster: received grants from Boehringer-Ingelheim, Roche, BristolMyers Squibb. Sandrine Aspeslagh: speaker's fees from Bristol-Myers Squibb, Roche, Astra Zeneca, Merck and Novartis. Bart Neyns: Honoraria - Bristol-Myers Squibb; Merck Sharp \& Dohme; Novartis; Roche, Consulting or Advisory Role - Bristol-Myers Squibb; Merck Sharp \& Dohme; Novartis; Roche Speakers' Bureau - Novartis Travel, Accommodations, Expenses Amgen; Bristol-Myers Squibb; Merck Sharp \& Dohme; Novartis; Roche. The other authors have nothing to disclose.

\section{Funding}

This research did not receive any specific grant from funding agencies in the public, commercial or not-for-profit-sector.

\section{Author contribution statement}

$\mathrm{J} M \mathrm{~K} d \mathrm{~F}, \mathrm{~A} \vee \mathrm{K}$ and $\mathrm{B} \vee$ planned the concept of this review. J M K d F, TV and $A \vee K$ carried out the literature search. J M K d F and $A \vee K$ performed the manuscript selection, data extraction and analysis. B J V D A performed HLA genotyping. J M K d F, B J V D A and A V K categorized the HLA genotypes. $\mathrm{J} M \mathrm{~K} d \mathrm{~F}$ and $\mathrm{A} V \mathrm{~K}$ drafted the manuscript. B O R provided the figure explaining the pathophysiology. All authors critically reviewed, revised and contributed to the final article.

\section{References}

1 Sanmamed MF \& Chen L. A paradigm shift in cancer immunotherapy: from enhancement to normalization. Cell 2018 175 313-326. (https://doi.org/10.1016/j.cell.2018.09.035)

2 Barroso-Sousa R, Barry WT, Garrido-Castro AC, Hodi FS, Min L, Krop IE \& Tolaney SM. Incidence of endocrine dysfunction following the use of different immune checkpoint inhibitor regimens: a systematic review and meta-analysis. JAMA Oncology 20184 173-182. (https://doi.org/10.1001/jamaoncol.2017.3064)

3 Sznol M, Postow MA, Davies MJ, Pavlick AC, Plimack ER, Shaheen M, Veloski C \& Robert C. Endocrine-related adverse events associated with immune checkpoint blockade and expert insights on their management. Cancer Treatment Reviews 201758 70-76. (https://doi. org/10.1016/j.ctrv.2017.06.002)

4 Clotman K, Janssens K, Specenier P, Weets I \& De Block CEM. Programmed cell death-1 inhibitor-induced Type 1 diabetes mellitus. Journal of Clinical Endocrinology and Metabolism 2018103 3144-3154. (https://doi.org/10.1210/jc.2018-00728)

5 Haanen JBAG, Carbonnel F, Robert C, Kerr KM, Peters S, Larkin J, Jordan K \& Committee EG. Management of toxicities from immunotherapy: ESMO Clinical Practice Guidelines for diagnosis, treatment and follow-up. Annals of Oncology 201728 (Supplement 4) iv119-iv142. (https://doi.org/10.1093/annonc/mdx225)

6 Stamatouli AM, Quandt Z, Perdigoto AL, Clark PL, Kluger H, Weiss SA, Gettinger S, Sznol M, Young A, Rushakoff R et al. Collateral damage: insulin-dependent diabetes induced with checkpoint inhibitors. Diabetes 201867 1471-1480. (https://doi.org/10.2337/ dbi18-0002)

7 Ascierto PA, Palmieri G \& Gogas H. What is changing in the adjuvant treatment of melanoma? Oncotarget 20178 110735-110736. (https:// doi.org/10.18632/oncotarget.22988)

8 Hillier TA, Abbott RD \& Barrett EJ. Hyponatremia: evaluating the correction factor for hyperglycemia. American Journal of Medicine 1999106 399-403. (https://doi.org/10.1016/s0002-9343(99)00055-8)

9 Heimberg H, Nagy ZP, Somers G, De Leeuw I \& Schuit FC. Complementation of HLA-DQA and -DQB genes confers susceptibility and protection to insulin-dependent diabetes mellitus. Human Immunology 199233 10-17. (https://doi.org/10.1016/01988859(92)90046-P)

10 de Filette J, Jansen Y, Schreuer M, Everaert H, Velkeniers B, Neyns B $\&$ Bravenboer B. Incidence of thyroid-related adverse events in melanoma patients treated with pembrolizumab. Journal of Clinical Endocrinology and Metabolism 2016101 4431-4439. (https://doi. org/10.1210/jc.2016-2300)

11 Delivanis DA, Gustafson MP, Bornschlegl S, Merten MM, Kottschade L, Withers S, Dietz AB \& Ryder M. Pembrolizumab-induced thyroiditis: comprehensive clinical review and insights Into underlying involved mechanisms. Journal of Clinical Endocrinology and Metabolism 2017102 2770-2780. (https://doi.org/10.1210/jc.2017-00448)

12 Morganstein DL, Lai Z, Spain L, Diem S, Levine D, Mace C, Gore M \& Larkin J. Thyroid abnormalities following the use of cytotoxic T-lymphocyte antigen- 4 and programmed death receptor protein-1 inhibitors in the treatment of melanoma. Clinical Endocrinology 2017 86 614-620. (https://doi.org/10.1111/cen.13297)

13 Scott ES, Long GV, Guminski A, Clifton-Bligh RJ, Menzies AM \& Tsang VH. The spectrum, incidence, kinetics and management of endocrinopathies with immune checkpoint inhibitors for metastatic melanoma. European Journal of Endocrinology 2018178 173-180. (https://doi.org/10.1530/EJE-17-0810)

14 Marchand L, Thivolet A, Dalle S, Chikh K, Reffet S, Vouillarmet J, Fabien N, Cugnet-Anceau C \& Thivolet C. Diabetes mellitus induced by PD-1 and PD-L1 inhibitors: description of pancreatic endocrine and exocrine phenotype. Acta Diabetologica 201956 441-448. (https://doi.org/10.1007/s00592-018-1234-8)

15 Matsumura K, Nagasawa K, Oshima Y, Kikuno S, Hayashi K, Nishimura A, Okubo M, Uruga H, Kishi K, Kobayashi T et al. Aggravation of diabetes, and incompletely deficient insulin secretion in a case with type 1 diabetes-resistant HLA DRB1*15:02 treated with nivolumab. Journal of Diabetes Investigation 20179 438-441. (https:// doi.org/10.1111/jdi.12679)

16 Lowe JR, Perry DJ, Salama AK, Mathews CE, Moss LG \& Hanks BA. Genetic risk analysis of a patient with fulminant autoimmune type 1 diabetes mellitus secondary to combination ipilimumab and nivolumab immunotherapy. Journal for ImmunoTherapy of Cancer 20164 89. (https://doi.org/10.1186/s40425-016-0196-z)

17 Okamoto M, Okamoto M, Gotoh K, Masaki T, Ozeki Y, Ando H, Anai M, Sato A, Yoshida Y, Ueda S et al. Fulminant type 1 diabetes 
mellitus with anti-programmed cell death-1 therapy. Journal of Diabetes Investigation 20167 915-918. (https://doi.org/10.1111/ jdi.12531)

18 Hughes J, Vudattu N, Sznol M, Gettinger S, Kluger H, Lupsa B \& Herold KC. Precipitation of autoimmune diabetes with anti-PD-1 immunotherapy. Diabetes Care 201538 e55-e57. (https://doi. org/10.2337/dc14-2349)

19 Capitao R, Bello C, Fonseca R \& Saraiva C. New onset diabetes after nivolumab treatment. BMJ Case Reports 20182018 Epub. (https:// doi.org/10.1136/bcr-2017-220999)

20 Chokr N, Farooq H \& Guadalupe E. Fulminant diabetes in a patient with advanced melanoma on nivolumab. Case Reports in Oncological Medicine 20182018 1-4. (https://doi.org/10.1155/2018/8981375)

21 Gunawan F, George E \& Roberts A. Combination immune checkpoint inhibitor therapy nivolumab and ipilimumab associated with multiple endocrinopathies. Endocrinology, Diabetes and Metabolism Case Reports 20182018 Epub. (https://doi.org/10.1530/EDM-170146)

22 Ho WJ, Rooper L, Sagorsky S \& Kang H. A robust response to combination immune checkpoint inhibitor therapy in HPV-related small cell cancer: a case report. Journal for ImmunoTherapy of Cancer 20186 33. (https://doi.org/10.1186/s40425-018-0348-4)

23 Lee S, Morgan A, Shah S \& Ebeling PR. Rapid-onset diabetic ketoacidosis secondary to nivolumab therapy. Endocrinology, Diabetes and Metabolism Case Reports 20182018 Epub. (https://doi. org/10.1530/EDM-18-0021)

24 Maamari J, Yeung SJ \& Chaftari PS. Diabetic ketoacidosis induced by a single dose of pembrolizumab. American Journal of Emergency Medicine 201937 376.e1-376.e2. (https://doi.org/10.1016/j. ajem.2018.10.040)

25 Magis Q, Gaudy-Marqueste C, Basire A, Loundou A, Malissen N, Troin L, Monestier S, Mallet S, Hesse S, Richard MA et al. Diabetes and blood glucose disorders under anti-PD1. Journal of Immunotherapy 201841 232-240. (https://doi.org/10.1097/CJI.0000000000000218)

26 Matsuura N, Koh G, Konishi C, Minamino S, Takahara Y, Harada H, Kodama K \& Emoto M. Fulminant onset of insulin-dependent diabetes with positive anti-GAD antibody titers during treatment with nivolumab in a patient with NSCLC. Cancer Immunology, Immunotherapy 201867 1417-1424. (https://doi.org/10.1007/s00262018-2203-3)

27 Meyers DE, Hill WF, Suo A, Jimenez-Zepeda V, Cheng T \& Nixon NA. Aplastic anemia secondary to nivolumab and ipilimumab in a patient with metastatic melanoma: a case report. Experimental Hematology and Oncology 20187 6. (https://doi.org/10.1186/s40164018-0098-5)

28 Omodaka T, Kiniwa Y, Sato Y, Suwa M, Sato M, Yamaguchi T, Sato A, Miyake T \& Okuyama R. Type 1 diabetes in a melanoma patient treated with ipilimumab after nivolumab. Journal of Dermatology 2018 45 e289-e290. (https://doi.org/10.1111/1346-8138.14331)

29 Patti R, Malhotra S, Sinha A, Singh P, Marcelin M \& Saxena A. Atezolizumab-induced new onset diabetes mellitus with ketoacidosis. American Journal of Therapeutics 201825 e565-e568. (https://doi. org/10.1097/MJT.0000000000000644)

30 Ramos-Levi AM, Rogado J, Sanchez-Torres JM, Colomer R \& Marazuela M. Nivolumab-induced thyroid dysfunction in patients with lung cancer. Endocrinologia, Diabetes y Nutricion 201966 26-34. (https://doi.org/10.1016/j.endinu.2018.05.005)

31 Sakurai K, Niitsuma S, Sato R, Takahashi K \& Arihara Z. Painless thyroiditis and fulminant type 1 diabetes mellitus in a patient treated with an immune checkpoint inhibitor, nivolumab. Tohoku Journal of Experimental Medicine 2018244 33-40. (https://doi.org/10.1620/ tjem.244.33)

32 Shiba M, Inaba $\mathrm{H}$, Ariyasu $\mathrm{H}$, Kawai S, Inagaki $\mathrm{Y}$, Matsuno S, Iwakura H, Yamamoto Y, Nishi M \& Akamizu T. Fulminant type 1 diabetes mellitus accompanied by positive conversion of anti-insulin antibody after the administration of anti-CTLA-4 antibody following the discontinuation of anti-PD-1 antibody. Internal Medicine $2018 \mathbf{5 7}$ 2029-2034. (https://doi.org/10.2169/internalmedicine.9518-17)

33 Takahashi A, Tsutsumida A, Namikawa K \& Yamazaki N. Fulminant type 1 diabetes associated with nivolumab in a patient with metastatic melanoma. Melanoma Research 201828 159-160. (https:// doi.org/10.1097/CMR.0000000000000418)

34 Tassone F, Colantonio I, Gamarra E, Gianotti L, Baffoni C, Magro G $\&$ Borretta G. Nivolumab-induced fulminant type 1 diabetes (T1D): the first Italian case report with long follow-up and flash glucose monitoring. Acta diabetologica 201856 489-490. (https://doi. org/10.1007/s00592-018-1246-4)

35 Tzoulis P, Corbett RW, Ponnampalam S, Baker E, Heaton D, Doulgeraki T \& Stebbing J. Nivolumab-induced fulminant diabetic ketoacidosis followed by thyroiditis. Endocrinology, Diabetes and Metabolism Case Reports 20182018 Epub. (https://doi.org/10.1530/ EDM-18-0111)

36 Villarreal J, Townes D, Vrablik M \& Ro K. A case of drug-induced severe endocrinopathies: what providers in the Emergency Department need to know. Advanced Emergency Nursing Journal 2018 40 16-20. (https://doi.org/10.1097/TME.0000000000000173)

37 Zaied AA, Akturk HK, Joseph RW \& Lee AS. New-onset insulindependent diabetes due to nivolumab. Endocrinology, Diabetes and Metabolism Case Reports 20182018 Epub. (https://doi.org/10.1530/ EDM-17-0174)

38 Araujo M, Ligeiro D, Costa L, Marques F, Trindade H, Correia JM \& Fonseca C. A case of fulminant Type 1 diabetes following anti-PD1 immunotherapy in a genetically susceptible patient. Immunotherapy 20179 531-535. (https://doi.org/10.2217/imt-2017-0020)

39 Atkins PW \& Thompson DM. Combination avelumab and utomilumab immunotherapy can induce diabetic ketoacidosis. Diabetes and Metabolism 201844 514-515. (https://doi.org/10.1016/j. diabet.2017.05.005)

40 Chae YK, Chiec L, Mohindra N, Gentzler R, Patel J \& Giles F. A case of pembrolizumab-induced type- 1 diabetes mellitus and discussion of immune checkpoint inhibitor-induced type 1 diabetes. Cancer Immunology, Immunotherapy 201766 25-32. (https://doi.org/10.1007/ s00262-016-1913-7)

41 Chan PY, Hall P, Hay G, Cohen VML \& Szlosarek PW. A major responder to ipilimumab and nivolumab in metastatic uveal melanoma with concomitant autoimmunity. Pigment Cell and Melanoma Research 201730 558-562. (https://doi.org/10.1111/ pcmr.12607)

42 Changizzadeh PN, Mukkamalla SKR \& Armenio VA. Combined checkpoint inhibitor therapy causing diabetic ketoacidosis in metastatic melanoma. Journal for ImmunoTherapy of Cancer 2017597. (https://doi.org/10.1186/s40425-017-0303-9)

43 Gauci ML, Laly P, Vidal-Trecan T, Baroudjian B, Gottlieb J, MadjlessiEzra N, Da Meda L, Madelaine-Chambrin I, Bagot M, Basset-Seguin N et al. Autoimmune diabetes induced by PD-1 inhibitor-retrospective analysis and pathogenesis: a case report and literature review. Cancer Immunology, Immunotherapy 201766 1399-1410. (https://doi. org/10.1007/s00262-017-2033-8)

44 Godwin JL, Jaggi S, Sirisena I, Sharda P, Rao AD, Mehra R \& Veloski C. Nivolumab-induced autoimmune diabetes mellitus presenting as diabetic ketoacidosis in a patient with metastatic lung cancer. Journal for ImmunoTherapy of Cancer 20175 40. (https://doi. org/10.1186/s40425-017-0245-2)

45 Hickmott L, De La Pena H, Turner H, Ahmed F, Protheroe A, Grossman A \& Gupta A. Anti-PD-L1 atezolizumab-induced autoimmune diabetes: a case report and review of the literature. Targeted Oncology 201712 235-241. (https://doi.org/10.1007/s11523017-0480-y)

46 Ishikawa K, Shono-Saito T, Yamate T, Kai Y, Sakai T, Shimizu F, Yamada Y, Mori H, Noso S, Ikegami $\mathrm{H}$ et al. A case of fulminant type 1 diabetes mellitus, with a precipitous decrease in pancreatic volume, induced by nivolumab for malignant melanoma: analysis of HLA 
and CTLA-4 polymorphisms. European Journal of Dermatology 201727 184-185. (https://doi.org/10.1684/ejd.2016.2923)

47 Kapke J, Shaheen Z, Kilari D, Knudson P \& Wong S. Immune checkpoint inhibitor-associated Type 1 diabetes mellitus: case series, review of the literature, and optimal management. Case Reports in Oncology 201710 897-909. (https://doi.org/10.1159/000480634)

48 Kumagai R, Muramatsu A, Nakajima R, Fujii M, Kaino K, Katakura Y, Okumura N, Ohara G, Kagohashi K, Satoh H et al. Acute-onset type 1 diabetes mellitus caused by nivolumab in a patient with advanced pulmonary adenocarcinoma. Journal of Diabetes Investigation $2017 \mathbf{8}$ 798-799. (https://doi.org/10.1111/jdi.12627)

49 Leonardi GC, Oxnard GR, Haas A, Lang JP, Williams JS \& Awad MM. Diabetic ketoacidosis as an immune-related adverse event from pembrolizumab in non-small cell lung cancer. Journal of Immunotherapy 201740 249-251. (https://doi.org/10.1097/ CJI.0000000000000173)

50 Li L, Masood A, Bari S, Yavuz S \& Grosbach AB. Autoimmune diabetes and thyroiditis complicating treatment with nivolumab. Case Reports in Oncology 201710 230-234. (https://doi. org/10.1159/000456540)

51 Marchand L, Paulus V, Fabien N, Perol M, Thivolet C, Vouillarmet J $\&$ Saintigny P. Nivolumab-induced acute diabetes mellitus and hypophysitis in a patient with advanced pulmonary pleomorphic carcinoma with a prolonged tumor response. Journal of Thoracic Oncology 201712 e182-e184. (https://doi.org/10.1016/j.jtho.2017.07.021)

52 Munakata W, Ohashi K, Yamauchi N \& Tobinai K. Fulminant type I diabetes mellitus associated with nivolumab in a patient with relapsed classical Hodgkin lymphoma. International Journal of Hematology 2017105 383-386. (https://doi.org/10.1007/s12185-0162101-4)

53 Smith-Cohn MA, Gill D, Voorhies BN, Agarwal N \& GarridoLaguna I. Case report: pembrolizumab-induced Type 1 diabetes in a patient with metastatic cholangiocarcinoma. Immunotherapy 20179 797-804. (https://doi.org/10.2217/imt-2017-0042)

54 Telo GH, Carvalhal GF, Cauduro CGS, Webber VS, Barrios CH $\&$ Fay AP. Fulminant type 1 diabetes caused by dual immune checkpoint blockade in metastatic renal cell carcinoma. Annals of Oncology 201728 191-192. (https://doi.org/10.1093/annonc/ mdw447)

55 Teramoto Y, Nakamura Y, Asami Y, Imamura T, Takahira S, Nemoto M, Sakai G, Shimada A, Noda M \& Yamamoto A. Case of type 1 diabetes associated with less-dose nivolumab therapy in a melanoma patient. Journal of Dermatology 201744 605-606. (https:// doi.org/10.1111/1346-8138.13486)

56 Thoreau B, Gouaillier-Vulcain F, Machet L, Mateus C, Robert C, Ferreira-Maldent N, Maillot F \& Lioger B. Acute lower limb ischaemia and diabetes in a patient treated with anti-PD1 monoclonal antibody for metastatic melanoma. Acta Dermato-Venereologica 201797 408-409. (https://doi.org/10.2340/00015555-2504)

57 Tsiogka A, Jansky GL, Bauer JW \& Koelblinger P. Fulminant type 1 diabetes after adjuvant ipilimumab therapy in cutaneous melanoma. Melanoma Research 201727 524-525. (https://doi.org/10.1097/ CMR.0000000000000384)

58 Usui Y, Udagawa H, Matsumoto S, Imai K, Ohashi K, Ishibashi M, Kirita K, Umemura S, Yoh K, Niho S et al. Association of serum anti-GAD antibody and HLA haplotypes with type 1 diabetes mellitus triggered by nivolumab in patients with non-small cell lung cancer. Journal of Thoracic Oncology 201712 e41-e43. (https://doi. org/10.1016/j.jtho.2016.12.015)

59 Way J, Drakaki A, Drexler A \& Freeby M. Anti-PD-L1 therapy and the onset of diabetes mellitus with positive pancreatic autoantibodies. BMJ Case Reports 20172017 Epub. (https://doi.org/10.1136/bcr-2017220415)

60 Aleksova J, Lau PK, Soldatos G \& McArthur G. Glucocorticoids did not reverse type 1 diabetes mellitus secondary to pembrolizumab in a patient with metastatic melanoma. BMJ Case Reports 20162016 Epub. (https://doi.org/10.1136/bcr-2016-217454)

61 Hansen E, Sahasrabudhe D \& Sievert L. A case report of insulindependent diabetes as immune-related toxicity of pembrolizumab: presentation, management and outcome. Cancer Immunology, Immunotherapy 201665 765-767. (https://doi.org/10.1007/s00262016-1835-4)

62 Hofmann L, Forschner A, Loquai C, Goldinger SM, Zimmer L, Ugurel S, Schmidgen MI, Gutzmer R, Utikal JS, Goppner D et al. Cutaneous, gastrointestinal, hepatic, endocrine, and renal sideeffects of anti-PD-1 therapy. European Journal of Cancer $2016 \mathbf{6 0}$ 190-209. (https://doi.org/10.1016/j.ejca.2016.02.025)

63 Humayun MA \& Poole R. A case of multiple immune toxicities from ipilimumab and pembrolizumab treatment. Hormones 201615 303-306. (https://doi.org/10.14310/horm.2002.1656)

64 Miyoshi Y, Ogawa O \& Oyama Y. Nivolumab, an anti-programmed cell death-1 antibody, induces fulminant type 1 diabetes. Tohoku Journal of Experimental Medicine 2016239 155-158. (https://doi. org/10.1620/tjem.239.155)

65 Gaudy C, Clevy C, Monestier S, Dubois N, Preau Y, Mallet S, Richard MA, Grob JJ, Valero R \& Beliard S. Anti-PD1 pembrolizumab can induce exceptional fulminant Type 1 diabetes. Diabetes Care 201538 e182-e183. (https://doi.org/10.2337/dc15-1331)

66 Martin-Liberal J, Furness AJ, Joshi K, Peggs KS, Quezada SA \& Larkin J. Anti-programmed cell death-1 therapy and insulindependent diabetes: a case report. Cancer Immunology, Immunotherapy 201564 765-767. (https://doi.org/10.1007/s00262-015-1689-1)

67 Galligan A, Xu W, Fourlanos S, Nankervis A, Chiang C, Mant AM, Parente P, Rischin D, Krishnamurthy B, Sandhu S et al. Diabetes associated with immune checkpoint inhibition: presentation and management challenges. Diabetic Medicine 201835 1283-1290. (https://doi.org/10.1111/dme.13762)

68 Gauci ML, Boudou P, Baroudjian B, Vidal-Trecan T, Da Meda L, Madelaine-Chambrin I, Basset-Seguin N, Bagot M, Pages C, Mourah S et al. Occurrence of type 1 and type 2 diabetes in patients treated with immunotherapy (anti-PD-1 and/or anti-CTLA-4) for metastatic melanoma: a retrospective study. Cancer Immunology, Immunotherapy 201867 1197-1208. (https://doi.org/10.1007/ s00262-018-2178-0)

69 Mellati M, Eaton KD, Brooks-Worrell BM, Hagopian WA, Martins R, Palmer JP \& Hirsch IB. Anti-PD-1 and anti-PDL-1 monoclonal antibodies causing Type 1 diabetes. Diabetes Care 201538 e137-e138. (https://doi.org/10.2337/dc15-0889)

70 Alhusseini M \& Samantray J. Autoimmune diabetes superimposed on type 2 diabetes in a patient initiated on immunotherapy for lung cancer. Diabetes and Metabolism 201743 86-88. (https://doi. org/10.1016/j.diabet.2016.05.007)

71 Hao JB, Renno A, Imam S, Alfonso-Jaume M, Elnagar N \& Jaume JC. Development of type 1 diabetes after cancer immunotherapy. AACE Clinical Case Reports 20173 e242-e245. (https://doi.org/10.4158/ EP161410.CR)

72 Shah M, Maxfield L, Feroz R. Rapid development of type 1 diabetes mellitus after initiation of anti-PD-1 therapy. International Journal of Cancer and Clinical Research 20183 066. (https://doi. org/10.23937/2378-3419/3/4/1066)

73 Long SA, Rieck M, Sanda S, Bollyky JB, Samuels PL, Goland R, Ahmann A, Rabinovitch A, Aggarwal S, Phippard D et al. Rapamycin/ IL-2 combination therapy in patients with type 1 diabetes augments Tregs yet transiently impairs beta-cell function. Diabetes 201261 2340-2348. (https://doi.org/10.2337/db12-0049)

74 Nakamura K, Kawasaki E, Imagawa A, Awata T, Ikegami H, Uchigata Y, Kobayashi T, Shimada A, Nakanishi K, Makino H et al. Type 1 diabetes and interferon therapy: a nationwide survey in Japan. Diabetes Care 201134 2084-2089. (https://doi.org/10.2337/ dc10-2274) 
75 Pihoker C, Gilliam LK, Hampe CS \& Lernmark A. Autoantibodies in diabetes. Diabetes 200554 (Supplement 2) S52-S61. (https://doi. org/10.2337/diabetes.54.suppl_2.s52)

76 Verge CF, Howard NJ, Rowley MJ, Mackay IR, Zimmet PZ, Egan M, Hulinska H, Hulinsky I, Silvestrini RA \& Kamath S. Anti-glutamate decarboxylase and other antibodies at the onset of childhood IDDM: a population-based study. Diabetologia 199437 1113-1120. (https:// doi.org/10.1007/BF00418375)

77 Campbell-Thompson M, Rodriguez-Calvo T \& Battaglia M. Abnormalities of the exocrine pancreas in Type 1 diabetes. Current Diabetes Reports 201515 79. (https://doi.org/10.1007/s11892-0150653-y)

78 Yadav D, Nair S, Norkus EP \& Pitchumoni CS. Nonspecific hyperamylasemia and hyperlipasemia in diabetic ketoacidosis: incidence and correlation with biochemical abnormalities. American Journal of Gastroenterology 200095 3123-3128. (https://doi. org/10.1111/j.1572-0241.2000.03279.x)

79 Remon J, Mezquita L, Corral J, Vilarino N \& Reguart N. Immunerelated adverse events with immune checkpoint inhibitors in thoracic malignancies: focusing on non-small cell lung cancer patients. Journal of Thoracic Disease 201810 (Supplement 13) S1516-S1533. (https://doi.org/10.21037/jtd.2017.12.52)

80 Michot JM, Ragou P, Carbonnel F, Champiat S, Voisin AL, Mateus C, Lambotte $O \&$ Annereau M. Significance of immune-related lipase increase induced by antiprogrammed death-1 or death ligand-1 antibodies: a brief communication. Journal of Immunotherapy $2018 \mathbf{4 1}$ 84-85. (https://doi.org/10.1097/CJI.0000000000000202)

81 Wright JJ, Salem JE, Johnson DB, Lebrun-Vignes B, Stamatouli A, Thomas JW, Herold KC, Moslehi J \& Powers AC. Increased reporting of immune checkpoint inhibitor-associated diabetes. Diabetes Care 201841 e150-e151. (https://doi.org/10.2337/dc18-1465)

82 Ansari MJ, Salama AD, Chitnis T, Smith RN, Yagita H, Akiba H, Yamazaki T, Azuma M, Iwai H, Khoury SJ et al. The programmed death-1 (PD-1) pathway regulates autoimmune diabetes in nonobese diabetic (NOD) mice. Journal of Experimental Medicine 2003198 63-69. (https://doi.org/10.1084/jem.20022125)

83 Liang SC, Latchman YE, Buhlmann JE, Tomczak MF, Horwitz BH, Freeman GJ \& Sharpe AH. Regulation of PD-1, PD-L1, and PD-L2 expression during normal and autoimmune responses. European Journal of Immunology 200333 2706-2716. (https://doi.org/10.1002/ eji.200324228)

84 Keir ME, Butte MJ, Freeman GJ \& Sharpe AH. PD-1 and its ligands in tolerance and immunity. Annual Review of Immunology 200826 677-704. (https://doi.org/10.1146/annurev. immunol.26.021607.090331)

85 Paterson AM, Brown KE, Keir ME, Vanguri VK, Riella LV, Chandraker A, Sayegh MH, Blazar BR, Freeman GJ \& Sharpe AH. The programmed death-1 ligand 1:B7-1 pathway restrains diabetogenic effector T cells in vivo. Journal of Immunology 2011187 1097-1105. (https://doi.org/10.4049/jimmunol.1003496)

86 Shieh SJ, Chou FC, Yu PN, Lin WC, Chang DM, Roffler SR \& Sytwu HK. Transgenic expression of single-chain anti-CTLA-4 Fv on beta cells protects nonobese diabetic mice from autoimmune diabetes. Journal of Immunology 2009183 2277-2285. (https://doi. org/10.4049/jimmunol.0900679)

87 Kavvoura FK \& Ioannidis JP. CTLA-4 gene polymorphisms and susceptibility to type 1 diabetes mellitus: a HuGE Review and metaanalysis. American Journal of Epidemiology 2005162 3-16. (https:// doi.org/10.1093/aje/kwi165)

88 Blomhoff A, Lie BA, Myhre AG, Kemp EH, Weetman AP, Akselsen HE, Huseby ES \& Undlien DE. Polymorphisms in the cytotoxic T lymphocyte antigen-4 gene region confer susceptibility to Addison's disease. Journal of Clinical Endocrinology and Metabolism 200489 3474-3476. (https://doi.org/10.1210/jc.2003-031854)

89 Ueda H, Howson JM, Esposito L, Heward J, Snook H, Chamberlain G Rainbow DB, Hunter KM, Smith AN, Di Genova G et al. Association of the T-cell regulatory gene CTLA4 with susceptibility to autoimmune disease. Nature 2003423 506-511. (https://doi. org/10.1038/nature01621)

90 Ni R, Ihara K, Miyako K, Kuromaru R, Inuo M, Kohno H \& Hara T. PD-1 gene haplotype is associated with the development of type 1 diabetes mellitus in Japanese children. Human Genetics $2007 \mathbf{1 2 1}$ 223-232. (https://doi.org/10.1007/s00439-006-0309-8)

91 Gu Y, Xiao L, Gu W, Chen S, Feng Y, Wang J, Wang Z, Cai Y, Chen H, $\mathrm{Xu} X$ et al. Rs2227982 and rs2227981 in PDCD1 gene are functional SNPs associated with T1D risk in East Asian. Acta Diabetologica 2018 55 813-819. (https://doi.org/10.1007/s00592-018-1152-9)

92 Nielsen C, Hansen D, Husby S, Jacobsen BB \& Lillevang ST. Association of a putative regulatory polymorphism in the PD-1 gene with susceptibility to type 1 diabetes. Tissue Antigens $2003 \mathbf{6 2}$ 492-497. (https://doi.org/10.1046/j.1399-0039.2003.00136.x)

93 Tsutsumi Y, Jie X, Ihara K, Nomura A, Kanemitsu S, Takada H \& Hara T. Phenotypic and genetic analyses of T-cell-mediated immunoregulation in patients with Type 1 diabetes. Diabetic Medicine 200623 1145-1150. (https://doi.org/10.1111/j.14645491.2006.01951.x)

94 Fujisawa R, Haseda F, Tsutsumi C, Hiromine Y, Noso S, Kawabata Y, Mitsui S, Terasaki J, Ikegami H, Imagawa A et al. Low programmed cell death-1 (PD-1) expression in peripheral CD4(+) T cells in Japanese patients with autoimmune type 1 diabetes. Clinical and Experimental Immunology 2015180 452-457. (https://doi. org/10.1111/cei.12603)

95 Granados HM, Draghi 2nd A, Tsurutani N, Wright K, Fernandez ML, Sylvester FA \& Vella AT. Programmed cell death-1, PD-1, is dysregulated in T cells from children with new onset type 1 diabetes. PLoS ONE 201712 e0183887. (https://doi.org/10.1371/journal. pone.0183887)

96 Jago CB, Yates J, Camara NO, Lechler RI \& Lombardi G. Differential expression of CTLA-4 among T cell subsets. Clinical and Experimental Immunology 2004136 463-471. (https://doi.org/10.1111/j.13652249.2004.02478.x)

97 Gray CP, Arosio P \& Hersey P. Heavy chain ferritin activates regulatory T cells by induction of changes in dendritic cells. Blood 200299 3326-3334. (https://doi.org/10.1182/blood.v99.9.3326)

98 Spence A \& Tang Q. Restoring regulatory T cells in Type 1 diabetes. Current Diabetes Reports 201616 110. (https://doi.org/10.1007/ s11892-016-0807-6)

99 Gerold KD, Zheng P, Rainbow DB, Zernecke A, Wicker LS \& Kissler S. The soluble CTLA- 4 splice variant protects from type 1 diabetes and potentiates regulatory T-cell function. Diabetes 201160 1955-1963. (https://doi.org/10.2337/db11-0130)

100 Perri V, Russo B, Crino A, Schiaffini R, Giorda E, Cappa M, Rosado MM \& Fierabracci A. Expression of PD-1 molecule on regulatory $\mathrm{T}$ lymphocytes in patients with insulin-dependent diabetes mellitus. International Journal of Molecular Sciences 201516 22584-22605. (https://doi.org/10.3390/ijms160922584)

101 Colli ML, Hill JLE, Marroqui L, Chaffey J, Dos Santos RS, Leete P, Coomans de Brachene A, Paula FMM, Op de Beeck A, Castela A et al. PDL1 is expressed in the islets of people with type 1 diabetes and is up-regulated by interferons-alpha and-gamma via IRF1 induction. EBioMedicine 201836 367-375. (https://doi.org/10.1016/j. ebiom.2018.09.040)

102 Osum KC, Burrack AL, Martinov T, Sahli NL, Mitchell JS, Tucker CG, Pauken KE, Papas K, Appakalai B, Spanier JA et al. Interferon-gamma drives programmed death-ligand 1 expression on islet beta cells to limit T cell function during autoimmune diabetes. Scientific Reports 20188 8295. (https://doi.org/10.1038/s41598-018-26471-9)

103 Steck AK \& Rewers MJ. Genetics of type 1 diabetes. Clinical Chemistry 201157 176-185. (https://doi.org/10.1373/clinchem.2010.148221)

104 Tsutsumi C, Imagawa A, Ikegami H, Makino H, Kobayashi T, Hanafusa T \& Japan Diabetes Society Committee on Type 1 Diabetes Mellitus Research. Class II HLA genotype in fulminant type 1 
diabetes: a nationwide survey with reference to glutamic acid decarboxylase antibodies. Journal of Diabetes Investigation 20123 62-69. (https://doi.org/10.1111/j.2040-1124.2011.00139.x)

105 Van der Auwera BJ, Schuit FC, Weets I, Ivens A, Van Autreve JE, Gorus FK \& Belgian Diabetes Registry. Relative and absolute HLADQA1-DQB1 linked risk for developing type I diabetes before 40 years of age in the Belgian population: implications for future prevention studies. Human Immunology 200263 40-50. (https://doi. org/10.1016/S0198-8859(01)00362-7)

106 Tuomi T, Santoro N, Caprio S, Cai M, Weng J \& Groop L. The many faces of diabetes: a disease with increasing heterogeneity. Lancet 2014 383 1084-1094. (https://doi.org/10.1016/S0140-6736(13)62219-9)

107 Szepietowska B, Glebocka A, Puch U, Gorska M \& Szelachowska M. Latent autoimmune diabetes in adults in a population-based cohort of Polish patients with newly diagnosed diabetes mellitus. Archives of Medical Science 20128 491-495. (https://doi.org/10.5114/ aoms.2012.29405)

108 Kawasaki E, Matsuura N \& Eguchi K. Type 1 diabetes in Japan. Diabetologia 200649 828-836. (https://doi.org/10.1007/s00125-0060213-8)

109 Buzzetti R, Zampetti S \& Maddaloni E. Adult-onset autoimmune diabetes: current knowledge and implications for management. Nature Reviews: Endocrinology 201713 674-686. (https://doi. org/10.1038/nrendo.2017.99)

110 Hanafusa T \& Imagawa A. Fulminant type 1 diabetes: a novel clinical entity requiring special attention by all medical practitioners. Nature Clinical Practice: Endocrinology and Metabolism 20073 36-45; quiz 2p. (https://doi.org/10.1038/ncpendmet0351)

111 Imagawa A, Hanafusa T, Awata T, Ikegami H, Uchigata Y, Osawa H, Kawasaki E, Kawabata Y, Kobayashi T, Shimada A et al. Report of the Committee of the Japan Diabetes Society on the research of fulminant and acute-onset type 1 diabetes mellitus: new diagnostic criteria of fulminant type 1 diabetes mellitus (2012). Journal of Diabetes Investigation 20123 536-539. (https://doi.org/10.1111/ jdi.12024)
112 Ehehalt S, Gauger N, Blumenstock G, Feldhahn L, Scheffner T, Schweizer R, Neu A \& DIARY-Group Baden-Wuerttemberg. Hemoglobin A1c is a reliable criterion for diagnosing type 1 diabetes in childhood and adolescence. Pediatric Diabetes 201011 446-449. (https://doi.org/10.1111/j.1399-5448.2009.00633.x)

113 Patel P \& Macerollo A. Diabetes mellitus: diagnosis and screening. American Family Physician 201081 863-870.

114 Byun DJ, Wolchok JD, Rosenberg LM \& Girotra M. Cancer immunotherapy - immune checkpoint blockade and associated endocrinopathies. Nature Reviews: Endocrinology 201713 195-207. (https://doi.org/10.1038/nrendo.2016.205)

115 Higham CE, Olsson-Brown A, Carroll P, Cooksley T, Larkin J, Lorigan P, Morganstein D, Trainer PJ \& Society for Endocrinology. SOCIETY FOR ENDOCRINOLOGY ENDOCRINE EMERGENCY GUIDANCE: Acute management of the endocrine complications of checkpoint inhibitor therapy. Endocrine Connections 20187 G1-G7. (https://doi.org/10.1530/EC-18-0068)

116 Brahmer JR, Lacchetti C, Schneider BJ, Atkins MB, Brassil KJ, Caterino JM, Chau I, Ernstoff MS, Gardner JM, Ginex P et al. Management of immune-related adverse events in patients treated with immune checkpoint inhibitor therapy: American Society of Clinical Oncology clinical practice guideline. Journal of Clinical Oncology 2018 36 1714-1768. (https://doi.org/10.1200/JCO.2017.77.6385)

117 Brahmer JR, Lacchetti C \& Thompson JA. Management of immunerelated adverse events in patients treated with immune checkpoint inhibitor therapy: American Society of Clinical Oncology clinical practice guideline summary. Journal of Oncology Practice 201814 247-249. (https://doi.org/10.1200/JOP.18.00005)

118 Sakai G, Saito D, Nakajima R, Hatano M, Noguchi Y, Kurihara S, Katayama S, Inoue I, Noda M \& Shimada A. Intrinsic insulin secretion capacity might be preserved by discontinuing antiprogrammed cell death protein 1 antibody treatment in 'antiprogrammed cell death protein 1 antibody-induced' fulminant type 1 diabetes. Journal of Diabetes Investigation 20189 448-449. (https:// doi.org/10.1111/jdi.12662)

Received 17 April 2019

Revised version received 18 June 2019

Accepted 19 July 2019 